\title{
Identifikasi Bidang Gelincir Dengan Eksplorasi Geolistrik Dalam Upaya Mitigasi Bencana Alam Tanah Longsor Di Desa Tinoor
}

\author{
Merscyas Tunenaa, As'aria*, Gerald H.Tamumtuana* \\ aJurusan Fisika, FMIPA, Unsrat, Manado
}

K A T K K N C I

Bidang gelincir

Geolistrik

Wenner Alfa

\begin{abstract}
A B S T R A K
Penelitian ini bertujuan untuk memetakan struktur bawah permukaan di Jalan Raya Manado - Tomohon, di Desa Tinoor untuk mencari keberadaan bidang gelincir sebagai mitigasi bencana alam tanah longsor. Pengukuran dalam penelitian ini dilakukan dengan menggunakan resistivitymeter MAE 612-EM, dengan jumlah elektroda yang dipakai 32 buah, spasi 2 meter, panjang lintasan 64 meter, jumlah ,lintasan 4, dan menggunakan metode geolistik resistivity konfigurasi Wenner Alfa. Data dengan format DAT diolah menggunakan software notepad dan res2dinv. Hasil pengolahan adalah tampang lintang resistivity 2D bawah permukaan yang menggambarkan keberadaan bidang gelincir.

Hasil penelitian diperoleh lapisan lempung pasiran yang merupakan

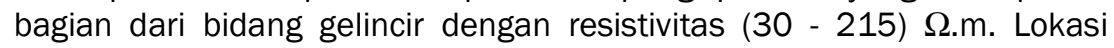
lapisan lempung pasiran pada lintasan 1 didapatkan 3 lokasi, lintasan 2 didapatkan 4 lokasi, lapisan 3 didapatkan 1 lokasi, dan lintasan 4 didapatkan 2 lokasi. Lokasi lempung pasiran terdapat pada kedalaman (1 - 6) meter dengan panjang (12 - 14) meter

A B S TR A C T

This research aims to map the subsurface structure on the Manado Tomohon main road, in Tinoor Village to find the existence of the slip surface as the mitigation of landslide disaster. The measurements in this research were carried out by using the MAE 612-EM resistivitymeters, with 32 electrodes, 2 meters spacing, 64 of meter line length, number of line 4, and using Wenner Alfa configuration geoelectric resistivity method. Data with DAT format is processed using notepad and res2dinv software's. The result of this prosessing is a cross-sectional resistivity $2 \mathrm{D}$, that describe the existence of the slip surface.

The result was obtained that the sandclay layer which is part of the slip surface with resistivity $30-215 \mathrm{ohm}$ meter. The location of sandclay layers on line 1 was found 3 locations, line 2 was found 4 locations, line 3 was found 1 location, and line 4 was found 2 locations. The location of the sandclay is at depth (1-6) meters with length (12-14) meters.
\end{abstract}

KEYWORDS

Slip surface

Geoelectric

Wenner Alpha

TERSEDIA ONLINE

01 Agustus 2018

1. Pendahuluan

Bencana merupakan suatu kejadian yang menimbulkan kerugian bagi setiap orang atau kelompok (Ao et al., 2014). Salah satu di antaranya yang cukup berbahaya serta dapat menimbulkan korban jiwa ialah tanah longor (Supper et al., 2014). Tanah longsor merupakan salah satu bencana yang sering terjadi pada musim hujan dan dipicu oleh gejala - gejala fisis seperti pergerakan tanah, pengikisan tanah oleh air hujan, dan penyerapan air oleh tanah. Selain dari gejala fisis tersebut, curah hujan juga memiliki peranan besar terjadinya tanah longsor (Finlay and Maguire, 1997). Curah hujan yang tinggi dan berkepajangan dapat menimbulkan pergerakan tanah akibat bertambahnya massa tanah serta kemiringan lereng dapat membuat tanah bergerak atau jatuh (Kirschbaum et al., 2011). Selain itu, pendugaan potensi tanah longsor 
pada suatu lokasi sangat dipengaruhi oleh ditemukannya bidang gelincir yang menjadi penyebab terbesar terjadinya bencana tanah longsor. Investigasi untuk bidang gelincir dapat dilakukan dengan banyak metode salah satunya metode geolistrik (Romando et al., 2016).

Material - material penyusun bidang gelincir dan longsoran memiliki sifat kelistrikan atau nilai tahanan jenis yang berbeda - beda tiap susunan lapisannya (Heradian dan Arman, 2015) yang dapat diukur.degan metode resistivitas. Desa Tinoor merupakan lokasi yang dilalui jalur penghubung antara Kota Tomohon dan Manado, banyak terjadi kejadian tanah longsor yang merugikan masyarakat desa tersebut. Penelitian ini bertujuan untuk memetakan struktur bawah permukaan di Desa Tinoor untuk mencari keberadaan bidang gelincir sebagai mitigasi bencana alam tanah longsor. Proses pengambilan data dilakukan di Desa Tinoor Kecamatan Tomohon Utara sedangkan untuk pengolahan di Laboratorium Geofisika FMIPA Universitas Sam Ratulangi Studi ini diharapkan dapat menjadi informasi bagi masyarakat Desa Tinoor serta referensi bagi pemerintah untuk potensi terjadinya bencana tanah longsor sebagai upaya mitigasi bencana alam.

\section{Material dan Metode}

\section{Alat dan Bahan yang Digunakan}

Alat - alat yang digunakan dalam penelitian ini adalah Geolistrik (multi-channel resistivity IP meter) MAE-X612-EM, GPS, Roll meter, dan Leptop Acer One 14.
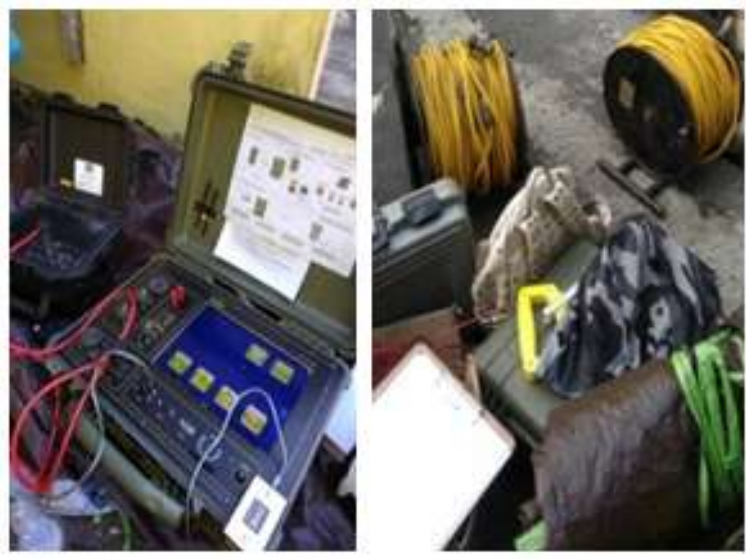

Gambar 1. Peralatan yang digunakan dalam penelitian

Alur kerja pada penelitian ini dimulai dengan mencari lokasi penelitian yang dilatar belakangi oleh banyaknya kejadian tanah longsor. Desa Tinoor Kecamatan Tomohon Utara merupakan area yang ditandai memiliki 60 titik yang berpotensi terjadinya tanah longsor menurut BNPB 2016. Lokasi penelitian yang diambil berada pada koordinat $\left(1^{0} 23^{\circ} 8,57^{m}-1^{0} 23^{\circ} 11^{\circ} 28^{m}\right)$ LU dan $\left(124^{\circ} 49^{\circ} 52,92^{m}-124^{\circ} 49^{\circ} 54,84^{m}\right)$ BT atau lebih tepatnya di Jalan Raya Manado - Tomohon km 16 Kecamatan Tomohon Utara. Lintasan pada penelitian ini yang telah ditentukan berjumlah 4 lintasan, masing - masing lintasan memiliki panjang 64 meter dengan jumlah 32 elektroda pada spasi 2 meter. Setelah banyaknya lintasan ditentukan maka penelitian dapat dilanjutkan dengan pembuatan desai survei agar memudahkan proses pengambilan data di lapangan. Metode geolistrik pada penelitian ini menggunakan konfigurasi Wenner Alfa, data yang diperoleh menggunakan metode ini berupa format DAT akan diolah menggunakan notepad untuk memasukkan nilai - nilai topografi dan diinterpretasi menggunakan res2dinv. Hasil yang diperoleh akan dianalisis tampang lintang bawah permukaannya yang apabila terdapat material lempung pasiran pembentuk bidang gelincir pada 4 lintasan penelitan maka kesimpulan yang diperoleh area sekitar lokasi penlitian tersebut kurang aman untuk ditinggali masyarakat.

\section{Hasil dan Pembahasan}

Mengidentifikasi adanya bidang luncuran sebagai penyebab terbesar terjadinya bencana tanah longsor menggunakan metode resistivitas merupakan suatu sarana pemecahan masalah untuk mengetahui lokasi dengan potensi tanah longsor di Desa Tinoor. Penelitian yang dilakasanakan dengan 4 lintasan dengan panjang masing - masing lintasan 64 meter dapat dilihat pada Gambar 4.1. Konfigurasi yang digunakan ialah konfigurasi Wenner Alfa dengan spasi jarak antara tiap elektroda yang telah ditentukan adalah 2 meter. Pengambilan data dilakukan pada saat kondisi cucaca hujan selama 2 hari.

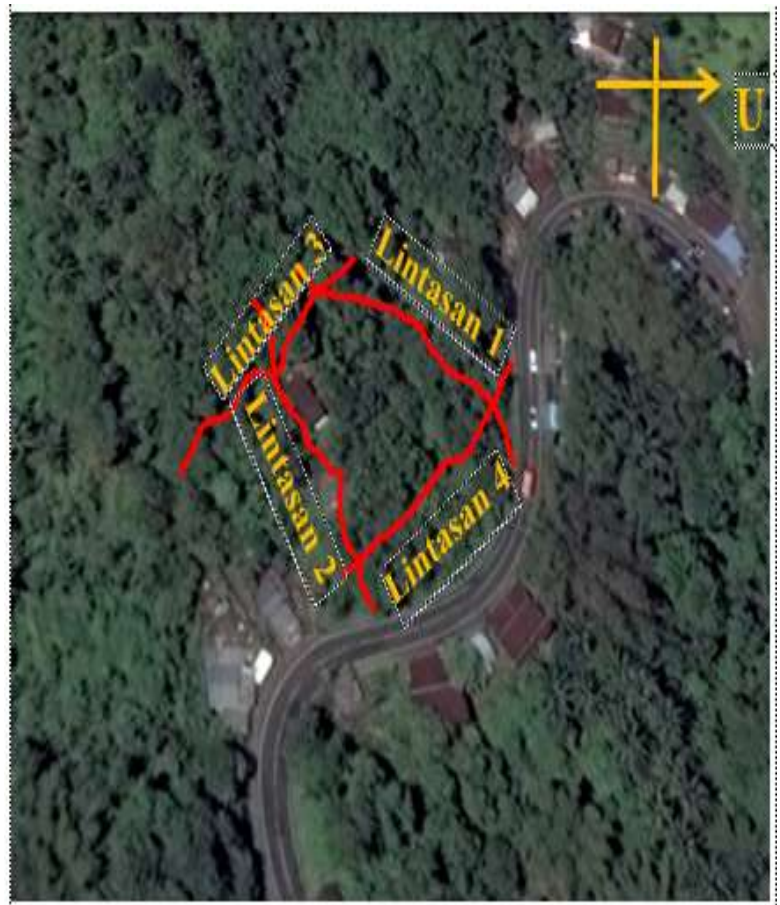

Gambar 2. Lintasan penelitian (Di atas map Google Earth

Identifikasi Bidang Luncuran

Identifikasi bidang luncuran bertujuan untuk mencari material dengan jenis tanah liat (clay) yang ditandai dengan nilai resistivitas (1 - 100) $\Omega \mathrm{m}$. Pada penelitian ini pencarian bidang luncuran dibagi menjadi 4 lintasan seperti pada Gambar 2. 


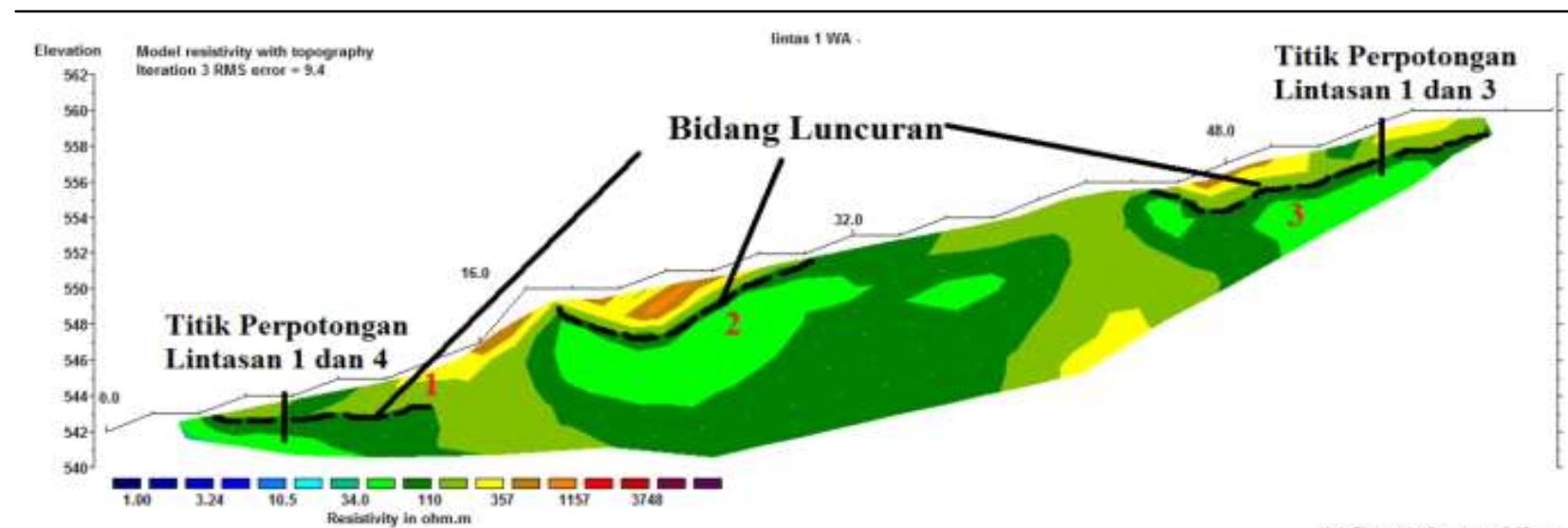

Herizental scale is 4t.10 pixels per unit spacing

Vertical exaggecation in modei section display - 0.08

First electrode is located at $0.0 \mathrm{~m}$.

Gambar 3. Lintasan 1 identifikasi bidang gelincir

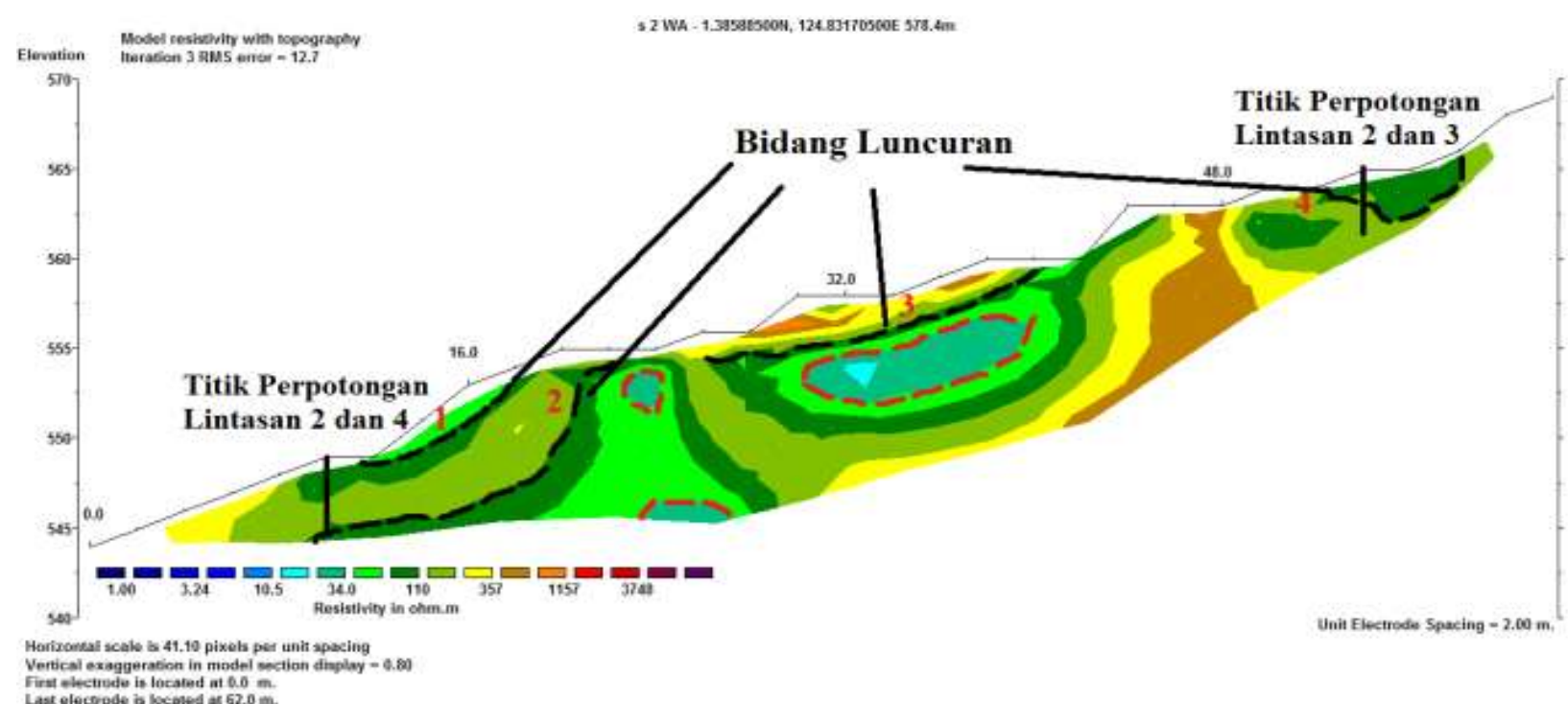

Gambar 4. Lintasan 2 identifikasi bidang gelincir

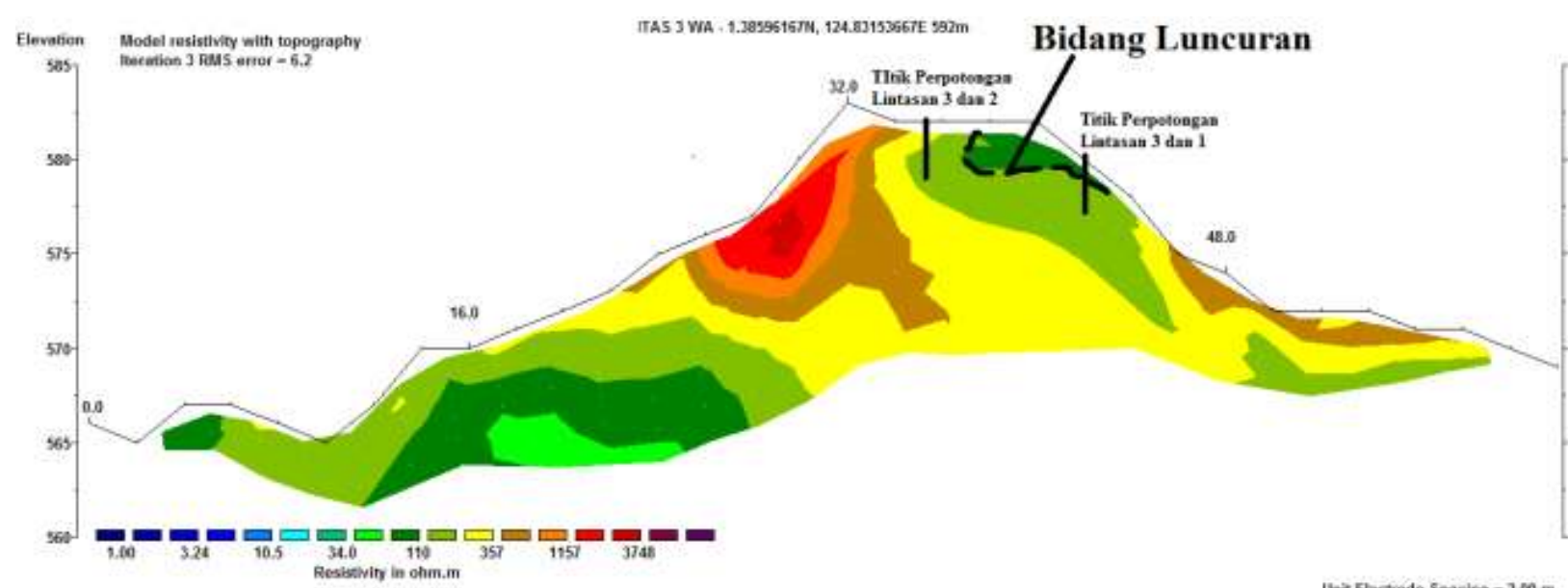

Gambar 5. Lintasan 3 identifikasi bidang gelincir 


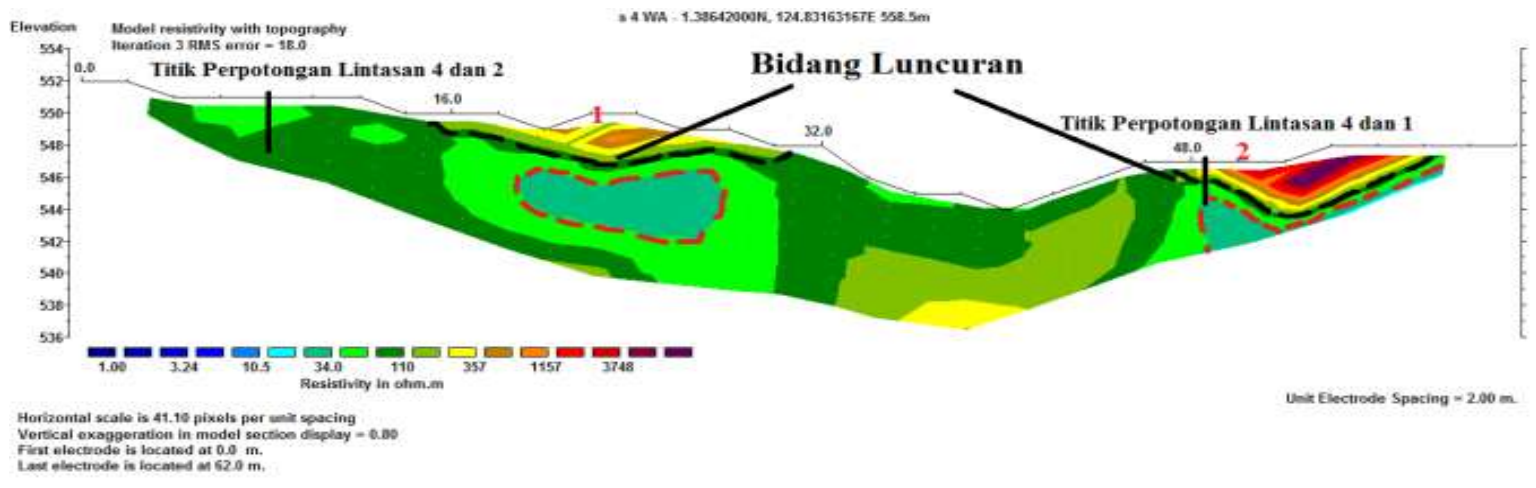

Gambar 6. Lintasan 4 identifikasi bidang gelincir

\section{Bidang Gelincir Pada Lintasan 1}

Lintasan yang pertama dapat dilihat pada Gambar 3 yaitu sebagian material tanah liat (clay) yang terlihat dengan warna hijau pada no. 1 yang dapat pula dipastikan sebagai bidang gelincir ditandai garis hitam putus - putus dengan kemungkinan terjadinya longsor sangat besar yaitu (8 - 10) meter dan pada kedalaman 1 meter karena sudah tidak ada lagi penahan pada bagian tersebut. Bidang gelincir yang ditunjukan pada no 2 terlihat adanya jalur serapan air yang akan menjadikan material dengan resistivitas (34 - 100) $\Omega$ berupa clay menjadi licin dan menggerakkan material di atasnya dengan panjang (12 - 14) meter dan kedalaman 3 meter Pada no ke 3 material clay tepat berada di bawah material dengan resistivitas (120 357) $\Omega . m$ ini memungkinkan terjadinya longsor dengan panjang (12 - 14) meter dan kedalaman 2 meter di bagian atas. Meninjau pada lintasan ke 1 ini memiliki nilai kemiringan lereng $16^{\circ}$ yang tergolong curam.

\section{Bidang Gelincir Pada Lintasan 2}

Gambar 4 pada lintasan yang ke dua ini untuk nomor 1 yang ditunjukan pada Gambar terlihat adanya bidang gelincir gelincir pada bagian atas material berwana kuning yang ditunjukan lewat garis hitam. Bidang gelincir yang terbentuk berada pada kedalaman 2 meter dengan panjang $(8-10)$ meter. Pada angka nomor 2 diperkirakan bidang gelincir yang terbentuk memiliki panjang (12 - 14) meter serta kedalaman 6 meter, angka 2 pada Gambar 4.7 menunjukan bahwa bidang gelincir yang terbentuk berada di bawah material keras yang diperkirakan sebagai batu pasir sampai serpihan dan kariki. Perlu diketahui bahwa pada bidang gelincir yang ke 2 ini terdapat rumah warga dipuncaknya, adanya jalur resapan air serta material penyusun bawah permukaan yang tersusun atas tanah liat dan aluvium akan menjadikan rumah tersebut sebagai bagian dari bencana tanah longsor. Pada nomor yang ke 3 bidang gelincir yang terlihat tepat berada di bawah rumah penduduk yang memiliki panjang (16 - 18) meter dan kedalaman 2 meter. Pada nomor yang ke 4 seperti yang ditunjukan pada Gambar 4.7 diprediksi sebagai jalur serapan air yang ditandai dengan warna hijau tua dan terdapat material keras di bawahnya.

Nomor yang ke 4 bidang gelincir membentuk cekungan dengan panjang $(4-6)$ meter pada kedalaman 2 meter dan diinterpretasikan sebagai longsor rotasional. Rata - rata kemiringan pada lintasan ini $23^{\circ}$ dan digolongkan curam

\section{Bidang Gelincir Pada Lintasan 3}

Lintasan ke 3 pada Gambar 5 terliahat terdapat 1 bidang gelincir pada lintasan ke 3 ini. Bidang gelincir yang terlihat memiliki panjang (6 - 8) meter pada kedalaman 2 meter dengan didominasi material dengan nilai resistivitas yang tinggi. Hal ini menjadikan lintasan ke 3 ini cukup aman dari bahaya tanah longsor, lintasan ke 3 ini sebelumnya pernah terjadi tanah longsor yang mengakibatkan titik perpotongan pada lintasan 1 dengan 3 dan lintasan 2 dengan 3 sangat berdekatan. Selain bidang gelincir yang terdapat pada pada titik perpotongan, tidak ada lagi potensi untuk terjadinya tanah longsor untuk lokasi tersebut.

\section{Bidang Gelincir Pada Lintasan 4}

Lintasan ke 4 pada Gambar 6 merupakan lintasan yang sejajar dengan Jalan Raya penghubung Manado - Tomohon. Pada lintasan ini terlihat adanya 2 bidang gelincir yang masing masing bidang gelincir tersebut terdapat area resapan air yang ditandai dengan garis merah tua pada Gambar 4.9. Pada bidang gelincir yang pertama, hasil interpretasi terlihat adanya kumpulan air yang terserap ke dalam tanah, hal ini menunjukan lapisan di atasnya merupakan lapisan dengan material yang mudah menyerap air berupa campuran clay dan pasir (sandclay) dengan resistivitas (30 - 215) $\Omega . m$ yang luasnya (12 - 14) meterpada kedalaman 2 meter. Pada bidang gelincir ke 2 yang ditunjukan pada Gambar 4.9 dengan panjang $(6-8)$ meter pada kedalaman 3 meter terlihat masih adanya lapisan dalam permukaan yang menampung air meskipun lapisan di atasnya merupakan lepisan yang keras. Pada bidang gelincir ke 2 ini, potensi longsor sangat tinggi karena material clay yang dapat membuat lapisan tersebut bergerak karena licin dan terjadi longsor 


\section{Kesimpulan}

Telah dilakukan penelitian di Jalan Manado Tomohon Desa Tinoor untuk mencari potensi terjadinya tanah longsor, maka diperoleh lapisan lempung pasiran yang merupakan bagian dari bidang luncuran dengan resistivitas (30 - 215) $\Omega . m$ pada 4 lintasan pengukuran di beberapa lokasi, yaitu:

1. Pada lintasan 1 diperoleh 3 lokasi lapisan lempung pasiran yang merupakan bagian dari bidang luncuran pada kedalaman (0 - 3) meter dengan panjang (8 - 10) meter untuk lokasi pertama dan (12 - 14) meter untuk lokasi ke dua dan ke tiga.

2. Pada lintasan 2 diperoleh 4 lokasi lapisan lempung pasiran yang merupakan bagian dari bidang luncuran pada kedalaman $(0-6)$ meter dengan panjang (8 - 10) meter untuk lokasi pertama, (12 - 14) meter untuk lokasi ke dua, (16 - 18) meter untuk lokasi ke tiga, dan (6 - 8) meter untuk lokasi ke empat.

3. Pada lintasan 3 diperoleh 1 lokasi lapisan lempung pasiran yang merupakan bagian dari bidang luncuran pada kedalaman (0 - 2) meter dengan panjang (8 - 10) meter.

4. Pada lintasan 4 diperoleh 2 lokasi lapisan lempung pasiran yang merupakan bagian dari bidang luncuran pada kedalaman (0 - 3) meter dengan panjang (12-14) meter untuk lokasi pertama dan (6 - 8) meter untuk lokasi ke dua.
Daftar Pustaka

Ao, M., Zhu J., Wang, C. and Yu, X. 2014. Identification of Landslide Region Based On Topographic and Change Information. International Journal of Signal Processing, Image, and Pattern Recognition. 7: 121 - 134.

Finlay, P. J. and Maguire, P. K. The Relationship Between The Probabilitiy of Landslide Occurrence and Rainfall. Canada Geot ech Journal. 34: 811 - 824.

Heradian, E. A dan Arman, Y. Pendugaan Bidang Gelincir Tanah Longsor di Desa Aruk Kecamatan Sajingan Besar Kabupaten Sambas dengan Menggunakan Metode Tahanan Jenis. Prisma Fisika. 3(2):56 - 61

Kirschbaum, D., Adler, R and Adler, D., Lidart, C. P., Huffman, G. Global Distribution of Extreme Precipitation and High-Impact Landslide in 2010 Relative to Previous Years. Journal of Hydrometeorology. 13: 1536 - 1551.

Romando, I., Darsono., dan Koesuma, S. Identifikasi Bidang Gelincir di Dusun Dukuh, Desa Koripan, Kecamatan Matesih, Kabupaten Karanganyar, Menggunakan Metode Geolistrik Resistivitas Konfigurasi Wenner Alfa. Indonesian Journal of Applied Physics. 6: 88 - 96. 